\title{
Origin of 3 Rabid Terrestrial Animals in Raccoon Rabies Virus-Free Zone, Long Island, New York, USA, 2016-2017
}

Scott Brunt, Heather Solomon, Hilaire Leavitt, Erica Lasek-Nesselquist, Pascal LaPierre, Matt Shudt, Laura Bigler, Navjot Singh, April D. Davis

During 2016-2017, three rabid terrestrial animals were discovered in the raccoon rabies virus-free zone of Long Island, New York, USA. Whole-genome sequencing and phylogenetic analyses revealed the likely origins of the viruses, enabling the rabies outbreak response (often costly and time-consuming) to be done less expensively and more efficiently.

$\mathrm{R}$ abies has been endemic to the eastern United States in raccoons (Procyon lotor) since 1960 and endemic to New York, USA, since the 1990s (1). The spread of rabies virus from raccoons in the mid-Atlantic states to species in New York has been reconstructed with spatiogenetic and phylogenic analyses (2). Despite this spread, a few locations in the region, including Suffolk and Nassau Counties on Long Island, New York, have been considered to be rabies free since 2011 (3). Maintaining these areas as low risk for rabies substantially decreases the likelihood of human and animal exposure to rabies virus and dramatically reduces the expenses paid for postexposure rabies virus treatments and rabies control (4).

To identify any breaches in the elimination zone, Nassau and Suffolk County health departments, veterinarians, and wildlife control officers routinely submit animals with clinical signs compatible with rabies for rabies virus testing to the New York State Department of Health Rabies Laboratory (Slingerlands, New York, USA). Before 2016, rabies had not been report-

Author affiliations: New York State Department of Health, Albany, New York, USA (S. Brunt, H. Solomon, E. Lasek-Nesselquist,

P. LaPierre, M. Shudt, N. Singh, A.D. Davis); Connecticut Department of Health, Rocky Hill, Connecticut, USA (H. Leavitt); Cornell University, Ithaca, New York, USA (L. Bigler)

DOI: https://doi.org/10.3201/eid2606.191700 ed in Suffolk County since 2009 or in Nassau County since 2007 (Figure 1) (5). During 2016-2017, rabies reappeared in Nassau and Suffolk Counties in 3 terrestrial animals: a raccoon (Procyon lotor), a river otter (Lontra canadensis), and a domestic cat (Felis catus). Here, we describe our efforts to identify the origins of these rabid animals and our contingency plans to eliminate further cases and restore the rabies virusfree zone status.

\section{The Study}

In March 2016, a rabid raccoon with neurologic signs was trapped in Hicksville in Nassau County. Realtime reverse transcription PCR (6) and Sanger sequencing demonstrated that the animal was infected with a raccoon rabies virus variant. A phylogenetic analysis of the full nucleoprotein and partial glycoprotein gene sequences did not provide us the resolution required for us to confidently identify where the virus had originated. At the time of this original analysis, whole-genome sequencing (WGS) was not available in our laboratory. We initiated enhanced rabies surveillance for $\approx 12$ months in Babylon and Huntington of Nassau County to determine if rabies virus was circulating locally by increasing the number of wild animals submitted for testing via trapping, roadkill collection, and animal control activities, but no animals were positive for rabies.

In December 2016, an employee of the New York State Department of Environmental Conservation (Albany, New York, USA) found a river otter on Sound Beach on the North Shore of Suffolk County; the otter was submitted to the Rabies Laboratory of the New York State Department of Health in February 2017. After the otter was determined to be rabies virus positive, our goal was to ascertain by WGS and sequence analysis where the otter was exposed, 


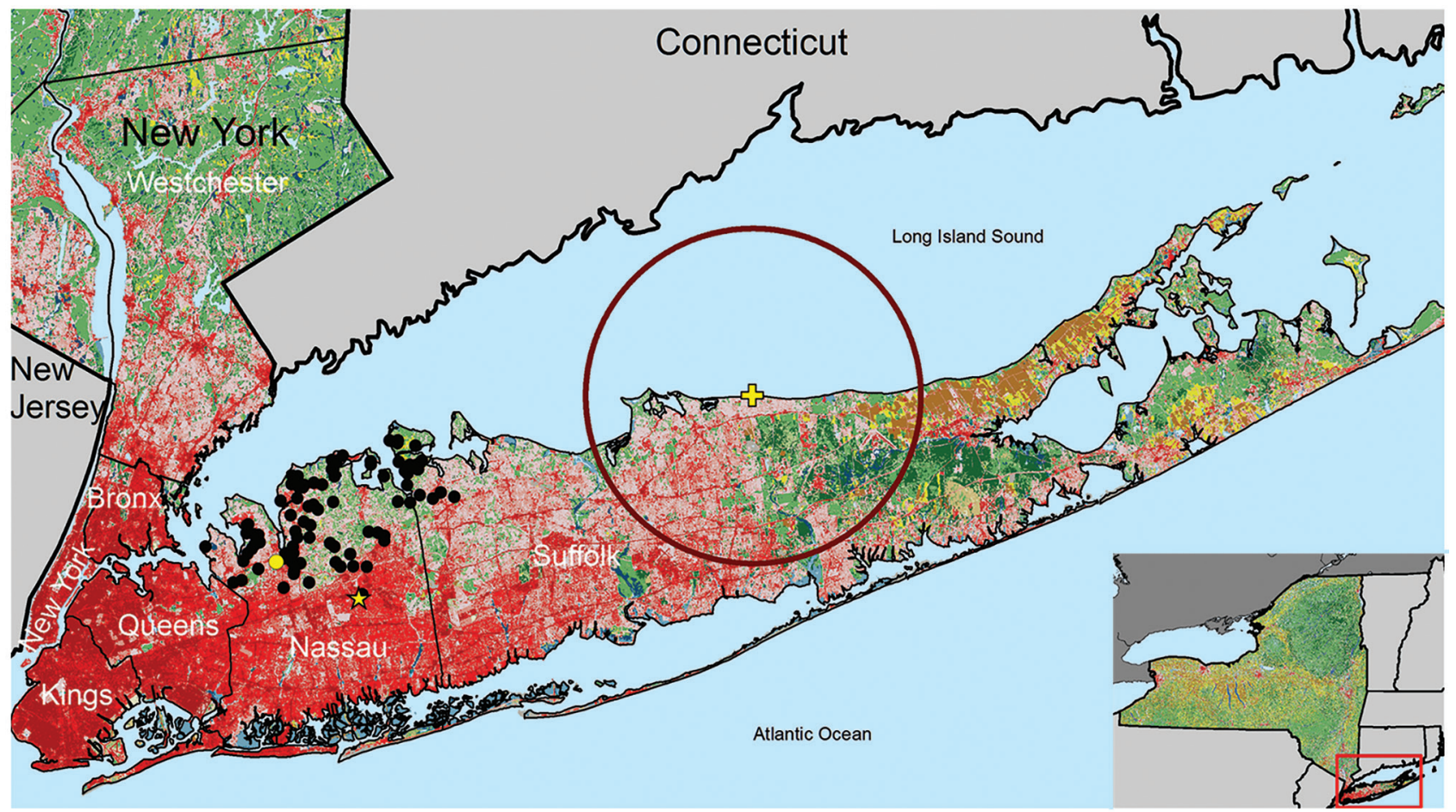

\section{Rabies cases \\ - Cat (2017) \\ - Raccoons (2004-2009) \\ 乡 River otter (2016) \\ th Raccoon (2016) \\ Boundary}
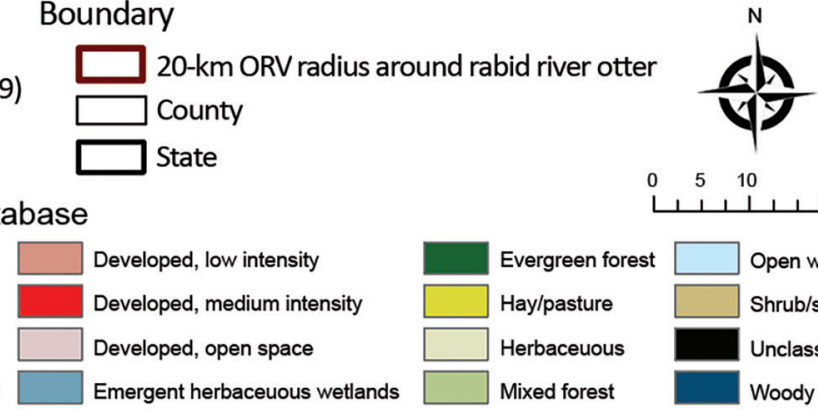

National land cover database
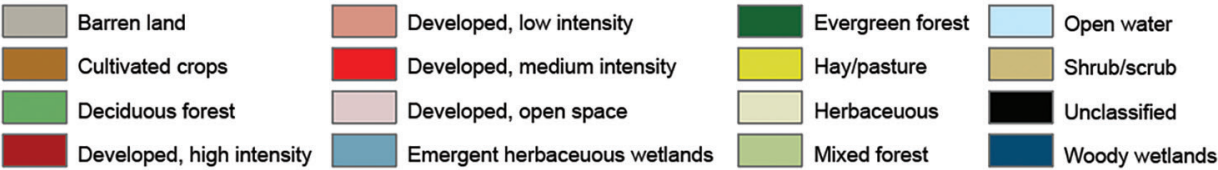

Figure 1. Locations of rabid raccoon, river otter, and cat in raccoon rabies virus-free zone, Nassau and Suffolk Counties, Long Island, New York, USA, 2016-2017. Locations of rabid raccoons found in these counties before they became raccoon rabies virus free are also indicated. The $20-\mathrm{km}$ radius originally proposed for the distribution of ORV if rabies virus had become reestablished in raccoon rabies virus-free zone is indicated. Inset indicates location of Long Island in New York. ORV, oral rabies vaccine.

which would help us determine which supplementary contingency actions were required.

In November 2017, a cat with neurologic signs that bit a veterinary staff member in Nassau County was submitted for testing. After determining this cat was positive for rabies virus, we included this case in the study.

When the raccoon was originally discovered on Long Island, we had contacted multiple state and federal agencies to discuss contingency plans for containing a possible rabies outbreak. We agreed to limit the contingency actions at that juncture to 12 months' enhanced surveillance, public health alerts to educate citizens, and reminders about free rabies virus vaccine clinics for domestic animals. Only in the event that other rabid animals were discovered during this time would wildlife trap, vaccinate, and release programs be implemented and oral rabies virus vaccine baits be distributed $(4,5,7)$. These vaccination programs can be expensive, so they are used conservatively as last resort efforts. The cost of the raccoon rabies virus elimination program that occurred on Long Island during 2006-2010 was $\approx \$ 2.6$ million (4).

The contingency plan to respond to the rabid river otter was initially to deploy oral rabies vaccine around a $20-\mathrm{km}$ radius of Sound Beach Long Island, covering nearly all of central Suffolk County (Figure 1). Costs would have exceeded $\$ 200,000$ as 120,000 baits would need to have been spread by foot, vehicle, and aircraft over a 636.6- $\mathrm{km}^{2}$ area during spring 2017. 
Because Wadsworth Center Sequencing Core (Slingerlands, New York, USA) charged $\approx \$ 250 /$ sample for WGS, we were able to save time and money by sam- pling animals and ruling out some areas as having local transmission and deescalating the initial plan. Applying WGS to priority samples has previously

\begin{tabular}{|c|c|c|c|c|c|}
\hline Laboratory ID no. & Collection date & Species & Location & Clade & GenBank accession no \\
\hline $731-18$ & 2018 Feb 5 & Raccoon & Denville, NJ, USA & 1 & MN418142 \\
\hline $2006-18$ & 2018 Apr 23 & Raccoon & Lincoln Park, NJ, USA & 1 & MN418156 \\
\hline 2834-17 & 2017 Jun 16 & Red Fox & New City, NY, USA & 1 & MN418149 \\
\hline KY026420 & 2004 Jun 21 & Raccoon & Genoa, NY, USA & 1 & $\dagger$ \\
\hline $7686-17$ & 2017 Oct 6 & Skunk & Troy, NY, USA & 1 & MN418168 \\
\hline $9049-17$ & 2017 Dec 16 & Raccoon & Hudson, NY, USA & 1 & MN418162 \\
\hline $259-17$ & 2017 Jan 23 & Raccoon & Clinton, NY, USA & 1 & MN418178 \\
\hline $8952-08$ & 2008 Nov 26 & Raccoon & Lloyd Harbor, NY, USA & 1 & MN418143 \\
\hline $135-09$ & 2009 Jan 8 & Raccoon & Huntington, NY, USA & 1 & MN418164 \\
\hline $7346-17$ & 2017 Sep 21 & Raccoon & Bronx, NY, USA & 1 & MN418174 \\
\hline $7314-17$ & 2017 Sep 20 & Raccoon & Bronx, NY, USA & 1 & MN418157 \\
\hline $7869-17$ & 2017 Aug 18 & Raccoon & Tarrytown, NY, USA & 1 & MN418153 \\
\hline $4980-17$ & 2017 Aug 8 & Gray Fox & Mahopac, NY, USA & 1 & MN418183 \\
\hline $8210-17$ & 2017 Nov 4 & Cat & Sea Cliff, NY, USA & 1 & MN418154 \\
\hline $2677-18$ & 2018 May 26 & Raccoon & Midland Park, NJ, USA & 1 & MN418169 \\
\hline $854-18$ & 2018 Feb 16 & Raccoon & Upper Saddle River, NJ, USA & 1 & MN418171 \\
\hline $871-17$ & 2017 Mar 3 & Raccoon & New Paltz, NY, USA & 1 & MN418145 \\
\hline $3617-17$ & 2016 Jul 12 & Raccoon & Cornwallville, NY, USA & 1 & MN418152 \\
\hline $8423-17$ & 2017 Nov 11 & Skunk & Accord, NY, USA & 1 & MN418172 \\
\hline $2847-17$ & 2017 Jun 6 & Gray Fox & Monticello, NY, USA & 1 & MN418158 \\
\hline $849-17$ & 2017 Mar 19 & Raccoon & Slate Hill, NY, USA & 1 & MN418167 \\
\hline KY026481 & 2008 Sep 18 & Raccoon & Charlotte, VT, USA & 1 subclade 1 & $\dagger$ \\
\hline KY026478 & 2006 Nov 16 & Raccoon & Stowe, VT, USA & 1 subclade 1 & $\dagger$ \\
\hline $8775-17$ & 2017 Dec 3 & Raccoon & Westerlo, NY, USA & 1 subclade 1 & MN418144 \\
\hline $5318-17$ & 2017 Aug 11 & Raccoon & Cobleskill, NY, USA & 1 subclade 1 & MN418147 \\
\hline KY026483 & 2011 Oct 23 & Skunk & Walden, VT, USA & 1 subclade 1 & $\dagger$ \\
\hline KY026482 & 2008 Sep 28 & Raccoon & Stowe, VT, USA & 1 subclade 1 & $\dagger$ \\
\hline $760-18$ & 2017 Aug 29 & Raccoon & Brownsville, VT, USA & 1 subclade 1 & MN418146 \\
\hline $763-18$ & 2017 Jun 20 & Gray Fox & Arlington, VT, USA & 1 subclade 1 & MN418177 \\
\hline $752-18$ & 2017 Apr 21 & Raccoon & Vergennes, VT, USA & 1 subclade 1 & MN418175 \\
\hline $751-18$ & 2017 Mar 3 & Red Fox & Bristol, VT, USA & 1 subclade 1 & MN418165 \\
\hline KY026479 & 2006 Dec 5 & Skunk & Bethel, VT, USA & 1 subclade 1 & $\dagger$ \\
\hline KY026480 & 2007 Dec 10 & Raccoon & Braintree, VT, USA & 1 subclade 1 & $\dagger$ \\
\hline CT608844 & 2016 Jul 6 & Raccoon & Ridgefield, CT, USA & 1 subclade 2 & MN418151 \\
\hline CT641269 & 2016 Nov 15 & Raccoon & Ridgefield, CT, USA & 1 subclade 2 & MN418163 \\
\hline $738-16$ & 2016 Mar 3 & Raccoon & Hicksville, NY, USA & 1 subclade 2 & MN418159 \\
\hline CT682858 & 2017 May 1 & Raccoon & Weston, CT, USA & 1 subclade 2 & MN418160 \\
\hline CT627067 & 2016 Feb 1 & Raccoon & Fairfield, CT, USA & 1 subclade 2 & MN418182 \\
\hline СT607469 & 2016 Jun 30 & Raccoon & Bridgeport, CT, USA & 1 subclade 2 & MN418155 \\
\hline СТ648095 & 2016 Dec 14 & Raccoon & Weston, CT, USA & 1 subclade 2 & MN418181 \\
\hline 441-17 & 2016 Dec 14 & Otter & Sound Beach, NY, USA & 1 subclade 2 & MN418161 \\
\hline $466-17$ & 2017 Feb 15 & Raccoon & Greene, NY, USA & 2 & MN418176 \\
\hline KY026416 & 1995 Dec 22 & Raccoon & Hounsfield, NY, USA & 2 & $\dagger$ \\
\hline KY026426 & 2000 Jan 12 & Raccoon & Wolfe Island, Ontario, Canada & 2 & $\dagger$ \\
\hline KY026424 & 1999 Dec 10 & Raccoon & Wolfe Island, Ontario, Canada & 2 & $t$ \\
\hline KY026427 & 2000 Jan 13 & Raccoon & Wolfe Island, Ontario, Canada & 2 & $t$ \\
\hline KY026422 & 1999 Jul 14 & Raccoon & Prescott, Ontario, Canada & 2 & $\dagger$ \\
\hline KY026423 & 1999 Sep 17 & Raccoon & $\begin{array}{l}\text { Oxford Station, Ontario, } \\
\text { Canada }\end{array}$ & 2 & $\dagger$ \\
\hline KY026450 & 2001 Apr 18 & Raccoon & Leeds, Ontario, Canada & 2 & $\dagger$ \\
\hline KY026417 & 1998 Nov 9 & Raccoon & Canton, NY, USA & 2 & $\dagger$ \\
\hline $37-18$ & 2018 Jan 3 & Raccoon & Plymouth, MA, USA & 3 & MN418173 \\
\hline СТ633269 & 2017 Oct 1 & Skunk & Groton, CT, USA & 3 & MN418148 \\
\hline $7844-17$ & 2017 Oct 12 & Cat & Providence, RI, USA & 3 & MN418170 \\
\hline $761-18$ & 2017 Aug 19 & Raccoon & Woodstock, VT, USA & 3 & MN418179 \\
\hline $186-18$ & 2017 Dec 6 & Skunk & Cutler, ME, USA & 3 & MN418180 \\
\hline $8994-17$ & 2017 Dec 15 & Raccoon & Washington, ME, USA & 3 & MN418184 \\
\hline KY026414 & 2013 May 21 & Raccoon & Waldo, ME, USA & 3 & $\dagger$ \\
\hline СT661885 & 2016 Feb 1 & Raccoon & New London, CT, USA & 3 & MN418150 \\
\hline
\end{tabular}

*Bold indicates rabies virus isolates that were found in the rabies virus-free zone. ID, identification.

†Previously deposited in GenBank (8). 

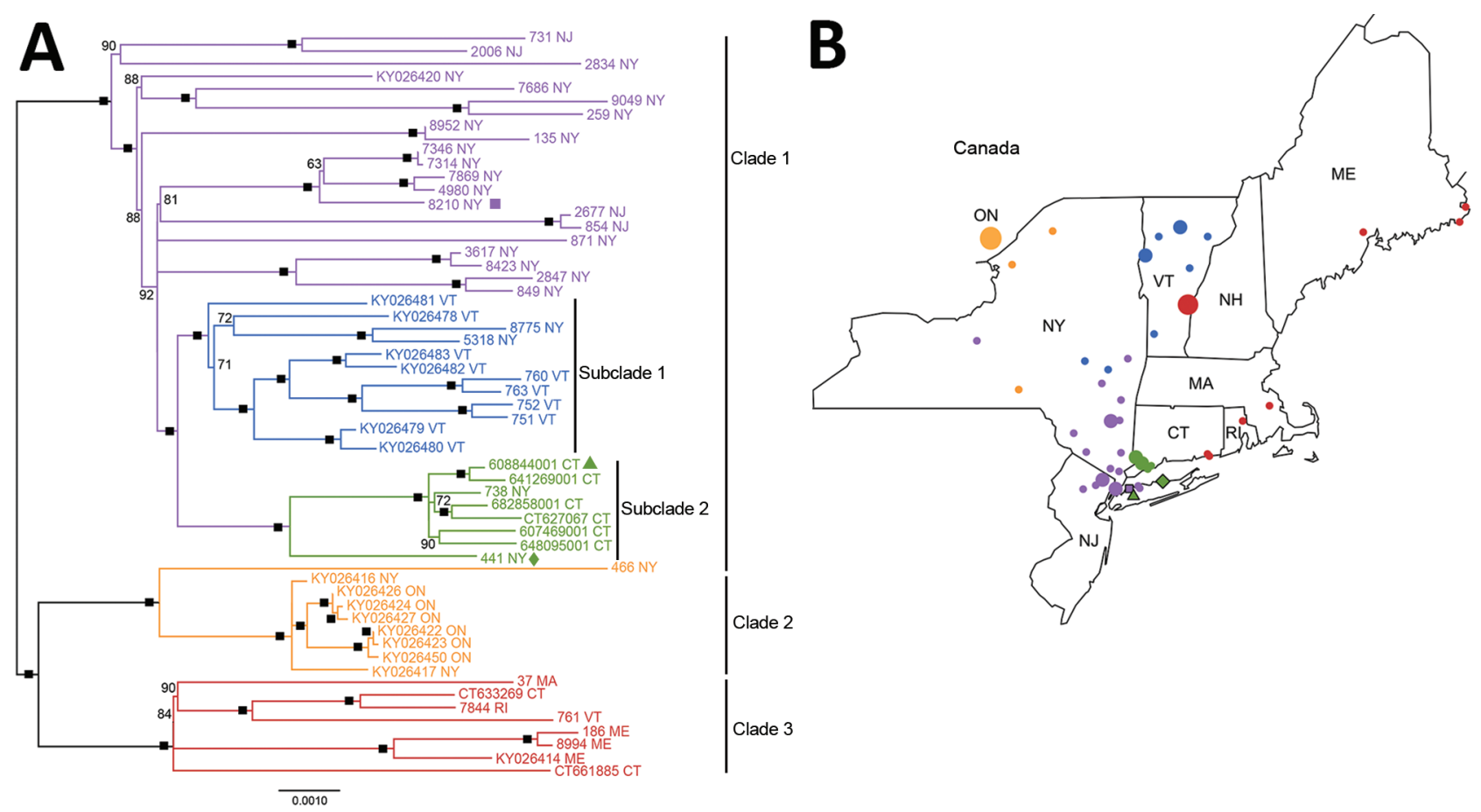

Figure 2. Maximum-likelihood whole-genome phylogeny and geographic location of rabies virus variants, northeastern United States and Canada, 2016-2017, including the rabid raccoon (green triangle), river otter (green diamond), and cat (purple square) found in raccoon rabies virus-free zones, Nassau and Suffolk Counties, Long Island, New York, USA . A) Midpoint-rooted, maximum-likelihood sequence analysis depicts the relationships among variants collected from New York, New Jersey, Massachusetts, Connecticut, Rhode Island, Vermont, and Maine, USA, and Ontario, Canada. Black boxes indicate nodes with $\geq 95 \%$ bootstrap support. Bootstrap support $\leq 50 \%$ is not shown. Scale bar indicates nucleotide substitutions per site. B) Location (by county) of virus isolation. Colors represent the major clades or subclades depicted in tree, and the size of symbols is proportional to the number of rabies samples isolated in that county. ON, Ontario.

been shown to be a viable strategy for public health laboratories to use in epidemiologic applications (8).

Using phylogenetic analysis (Table; Figure 2), we found that the raccoon in Hicksville was infected with a rabies virus variant consistent with those found in southwestern Connecticut. Considering the absence of local rabid wildlife with a similar rabies virus variant, we hypothesized that this raccoon was either accidentally or purposefully translocated into Long Island by human activity. Such translocation events were previously demonstrated with the linkage of an outbreak in Canada to a clade of raccoon rabies virus from upstate and central New York (9) and the spread of raccoon rabies virus up the East Coast of the United States $(2,8)$. Furthermore, although the range of the average raccoon is highly dependent on many factors, raccoon ranges have been established to rarely exceed $4 \mathrm{~km}$ (2.5 miles) $(10,11)$, well short of the 56-km (35-mile) distance from the Connecticut panhandle to Hicksville, New York.

Our phylogenetic analysis could not be used to conclusively determine where the rabies virus variant found in the river otter circulates, although the clade from Connecticut demonstrated the highest sequence similarity. Otters are found on the South Shores of Connecticut, Massachusetts, and Rhode Island and the North Shore of Long Island (12). They can swim $>32 \mathrm{~km}$ (20 miles) a day and occupy territories of considerable size (13). When found, the otter was extremely decomposed to the extent of being borderline untestable. We deduced that the otter was likely from coastal or even inland Connecticut on the basis of phylogenetic data, tissue quality, and species behavior and habitat, but we do not know for certain. Additional sampling from Connecticut could potentially result in the virus from the otter being nested definitively within clade 1 subclade 2 .

The rabid otter and raccoon most likely represent 2 separate incursion events, evidenced by the phylogenetic analysis. Because enhanced surveillance did not lead to the discovery of additional rabid animals during January 2017-December 2019 in the entirety of Suffolk and Nassau Counties, we can confidently stipulate that these were isolated events. Although we cannot state with conviction that no other animals 
became infected, these incursions appear to be short lived and self-limiting.

The rabid cat from November 2017 was briefly considered a continuation of this tentative Long Island rabies outbreak, but after several conversations with public health authorities and the pet owner, this cat was determined to have been unvaccinated and adopted $\approx 80 \mathrm{~km}$ (50 miles) away in Westchester County. Phylogenetic analysis confirmed the virus variant was consistent with those found in downstate New York (clade 1). Although international pet adoption often garners headlines, domestic animal adoption (14) and incidental rabies translocation remains a constant threat that can jeopardize the results of multimillion-dollar rabies elimination programs.

\section{Conclusions}

Using WGS of an assortment of viruses, we revealed the likely origins of 3 raccoon rabies virus variants from 3 animals that had unexpectedly broken into a rabies-free zone. Through intensified enhanced rabies surveillance and WGS, an expensive contingency plan to distribute baits on Long Island ultimately became unnecessary and was not implemented. This study demonstrates the utility of WGS and phylogenetics as part of a multifaceted rabies investigation with tangible real-world consequences.

\section{Acknowledgments}

We are grateful to Susan Nadin-Davis and Christine Fehlner-Gardiner for their invaluable discussions on WGS. Thank you to the Connecticut, Vermont, and New York City Public Health Laboratories for sharing their samples with us. We are also grateful to Wadsworth Center Sequencing core for their assistance and advice.

\section{About the Author}

Mr. Brunt is a research scientist working at the Rabies Laboratory of the New York State Department of Health in Slingerlands, New York, USA. His research interests include molecular diagnostics, whole-genome sequencing, and bioinformatics.

\section{References}

1. Recuenco S, Eidson M, Cherry B, Kulldorff M, Johnson G. Factors associated with endemic raccoon (Procyon lotor) rabies in terrestrial mammals in New York State, USA. Prev Vet Med. 2008;86:30-42. http://dx.doi.org/10.1016/ j.prevetmed.2008.03.001
2. Biek R, Henderson JC, Waller LA, Rupprecht CE, Real LA. A high-resolution genetic signature of demographic and spatial expansion in epizootic rabies virus. Proc Natl Acad Sci U S A. 2007;104:7993-8. http:/ / dx.doi.org/10.1073/ pnas.0700741104

3. Ma X, Monroe BP, Cleaton JM, Orciari LA, Li Y, Kirby JD, et al. Rabies surveillance in the United States during 2017. J Am Vet Med Assoc. 2018;253:1555-68. http:/ /dx.doi.org/ 10.2460/javma.253.12.1555

4. Elser JL, Bigler LL, Anderson AM, Maki JL, Lein DH, Shwiff SA. The economics of a successful raccoon rabies elimination program on Long Island, New York. PLoS Negl Trop Dis. 2016;10:e0005062. http:/ /dx.doi.org/10.1371/ journal.pntd.0005062

5. Bigler L, Ochwat J, Scarpitta S, Matthews B, Rudd R, Lein D. Oral rabies vaccination strategies toward raccoon rabies elimination in suburban Nassau and Suffolk Counties (Long Island, New York, USA). J Wildl Dis. 2019 In press.

6. Szanto AG, Nadin-Davis SA, Rosatte RC, White BN. Re-assessment of direct fluorescent antibody negative brain tissues with a real-time PCR assay to detect the presence of raccoon rabies virus RNA. J Virol Methods. 2011;174:110-6. http://dx.doi.org/10.1016/j.jviromet.2011.04.009

7. Slavinski S, Humberg L, Lowney M, Simon R, Calvanese N, Bregman B, et al. Trap-vaccinate-release program to control raccoon rabies, New York, USA. Emerg Infect Dis. 2012;18:1170-2. http:/ / dx.doi.org/10.3201/eid1807.111485

8. Nadin-Davis SA, Colville A, Trewby H, Biek R, Real L. Application of high-throughput sequencing to whole rabies viral genome characterisation and its use for phylogenetic re-evaluation of a raccoon strain incursion into the province of Ontario. Virus Res. 2017;232:123-33. http:/ /dx.doi.org/ 10.1016/j.virusres.2017.02.007

9. Van Paassen K. Southeastern N.Y. likely the source of Ontario racoon rabies. 2016 Jun 17 [cited 2019 Jan 14]. https://www.theglobeandmail.com/news/national/ southeastern-ny-likely-the-source-of-ontario-raccoon-rabiesoutbreak/article30503340

10. Jenkins SR, Perry BD, Winkler WG. Ecology and epidemiology of raccoon rabies. Rev Infect Dis. 1988;10 (Suppl 4):S620-5. http:/ /dx.doi.org/10.1093/clinids/10. Supplement_4.S620

11. Rosatte R, Sobey K, Donovan D, Bruce L, Allan M, Silver A, et al. Behavior, movements, and demographics of rabid raccoons in Ontario, Canada: management implications. J Wildl Dis. 2006;42:589-605. http://dx.doi.org/10.7589/ 0090-3558-42.3.589

12. Lariviere S, Walton LR. Lontra canadensis. Mamm Species. 1998;587:1-8. https://doi.org/10.2307/3504417

13. New York State Department of Environmental Conservation. River otter [cited 2019 Jan 19]. https:/ / www.dec.ny.gov/ animals/9355.html

14. Singh AJ, Chipman RB, de Fijter S, Gary R, Haskell MG, Kirby J, et al. Translocation of a stray cat infected with rabies from North Carolina to a terrestrial rabies-free county in Ohio, 2017. MMWR Morb Mortal Wkly Rep. 2018;67:1174-7. http:/ / dx.doi.org/10.15585/mmwr.mm6742a2

Address for correspondence: Scott Brunt, New York State Department of Health, 5668 State Farm Rd, Slingerlands, NY 12159, USA; email: scott.brunt@health.ny.gov 